\title{
Conditions and rate of extreme dunes abrasion at the Pomeranian Bay
}

\author{
Jacek Tylkowski \\ Institute of Geoecology and Geoinformation, Adam Mickiewicz University in Poznań, Poland, e-mail: jatyl@amu.edu.pl
}

\begin{abstract}
This paper presents the temporal and spatial variability of the abrasion dynamics of the dunes located on the coast of the Southern Baltic Sea within the Polish section of the Pomeranian Bay between 1986 and 2008. The study presents long-term tendencies and daily dynamics of coastal dunes abrasion, being the consequence of intensive storm surges. Systematic, quantitative measurements of the abrasion of dunes were performed by the Maritime Offices in Szczecin, Shupsk and Gdynia within the sections of the dune coast most severely affected by abrasion. To determine the origin of the abrasion of dunes, the key hydro-meteorological conditions that determine the geomorphological changes of coastal sea areas, such as types of atmospheric circulation and the maximal sea levels during storm surges, were reviewed. The study also shows the maximal sea level thresholds that can determine the potential dynamics of coastal dunes abrasion at the Pomeranian Bay.
\end{abstract}

Key words: abrasion of dunes, extreme geomorphological events, Baltic Sea coast, storm surges, atmospheric circulation

\section{Introduction}

Coastal dunes are a good geoindicator of geomorphological changes in the natural environment. They constitute a sensitive geological indicator of development and changes of marine coasts in the context of climatic changes, marine transgression and high frequencies of extreme storm surges (Carter 1988, Bird 1990, Carter, Wilson 1990, Nordstrom 2000, Łabuz 2013a). The coastal dunes of the Southern Baltic Sea are very varied as a result of the impact of a series of morphogenetic factors with their variable dynamics. The dune coastlines have been actively transformed under the influence of winds, being in particular subjected to intensive abrasion in the course of storm waving (Kostrzewski, Musielak 2008). In addition, due to landscape changes and tourists pressure, dune shores have undergone considerable anthropogenic degradation ( Łabuz 2004).

The Polish coastal area of the Pomeranian Bay covers a section of approximately $116 \mathrm{~km}$ length from Świnoujście to Gąski, which belongs to 3 physical-geographical units: Uznam and Wolin Islands, Trzebiatów Coast and Słowiński Coast (Kondracki 2000). Sandy dune coasts prevail over the Pomeranian Bay; however there are also cliffs within. Pleistocene high abrasive coasts cover 46 $\mathrm{km}$ of the Pomeranian Bay's coastline and include the following cliff sections: Sarbinowo, Ustronie Morskie, Śliwin, Trzęsacz, Pobierowo and Wolin (Subotowicz 1982). Dune coasts occur on about $60 \%$ of the Pomeranian Bay's coastline. On the dune coastlines of the Pomeranian Bay occurs sandbar sections: Resko Lake Sandbar, Liwia Łuża
Sanbar, Dziwnowska Sandbar and Świna Gate Sandbar. The dune coastline was formed in Holocene upon the retreat of Pleistocene glaciations. The development of such accumulative dune coastline has been the result of deposition of sandy sediments at the occurrence of littoral and aeolian processes. Within the Pomeranian Bay coastline, dunes primarily occur within spit sections and - to a smaller extent - within moraine areas (Łabuz 2005a).

The largest area of the Pomeranian Bay coastline consists of spit-dune forming variedly-aged dune ridges parallel to the coastline. Dune ridges within these spit sections occur in the following sequence: the youngest white dunes, then grey dunes and the oldest brown dunes located farthest from the coastline.

Sandbar-dune coasts along the Polish coastline of the Baltic Sea were formed within the last 5000 years at the stage of relative shore stabilization, upon the end of the marine transgression of the Atlantic period. Usually there is a coastal lake, a marine bay or a swampy river valley (glacial valley) area at the back of such dune ridges. Most commonly, coastlines of this type were formed at sections of former river estuaries where - as a result of the provision of sediments - sandy barriers were developed with dune ridges upon them (Fig. 1). Together with a slow rise of the sea level since about 3000 years, the coast of the Southern Baltic Sea begun to recede (including spit-dune sections of the coastline) (Tomczak 1995).

The least rarely occurring type of coastal dunes refers to dune coasts of moraine areas when Holocene sections entered a series of Pleistocene moraine clays or sandy 


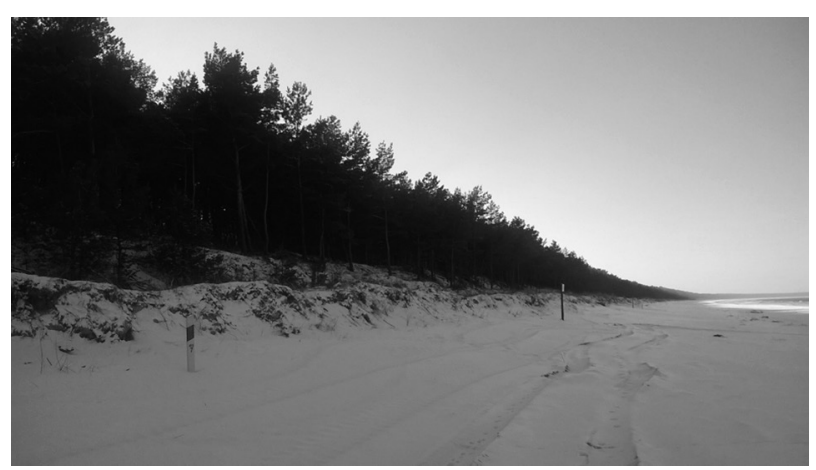

Fig. 1. Dune coastline of the Świna Gate Sandbar (after storm surge 06.12.2013)

dune ridges were formed at the base of moraine cliffs (Bohdziewicz 1963), for example at the Wolin Island between Wisełka and Grodno (Fig. 2).

The height of dune ridges along the Pomeranian Bay coastline is widely varied in spatial terms, from nearly 2 $\mathrm{m}$ in the proximity of the Resko Lake up to over $15 \mathrm{~m}$ at the Świna Gate Sandbar. The width dune ridges zone is also very varied, from nearly $200 \mathrm{~m}$ at the spit of Resko Lake up to over $1000 \mathrm{~m}$ at the Świna Sandbar (Labuz 2005b). The dune coastline of the Pomeranian Bay can be classified as a low coastline $(\mathrm{h}<8 \mathrm{~m})$ and - less frequently - as a medium coastline ( $\mathrm{h}=8-15 \mathrm{~m}$ ). In terms of developmental trends, the dune coastline of the Pomeranian Bay is characterized by the prevalence of destruction processes, marine abrasion (Bohdziewicz 1963).

The geographical characteristics of the Pomeranian Bay coastlines were a subject of research on both dune coasts (Borówka 1990, 1999, Musielak 1995, Racinowski 1995, Łabuz 2003, 2009, 2013a, Tylkowski 2011, Zawadzka-Kahlau 2012) and cliff coasts (Kostrzewski 1985, Kostrzewski, Zwoliński 1988, 1995, Kolander et al. 2013). Their sedimentary structures and spatial variability of particle grading of coastal sediments were dealt with, among others, by Krygowski et al. (1966), Sydor et al. (2011), Tylkowski, Samołyk (2011). The developmental reconstruction of dune coasts of the Świna Gate Sandbar

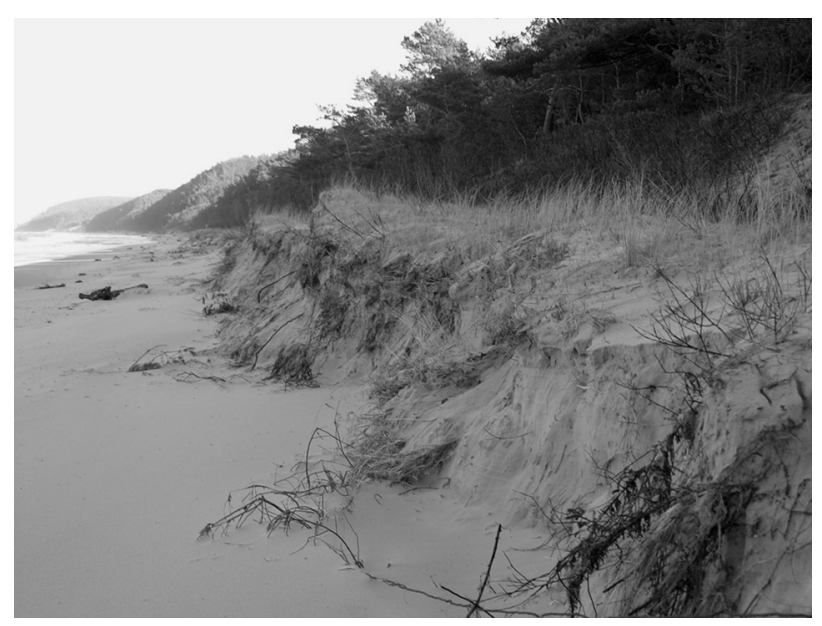

Fig. 2. Cliff coast with its front eroded dune in Grodno (20.01.2007) was presented by such researchers as Łabuz and Olechnowicz (2004). The detailed characteristics of a line-formed arrangement of dune ridges and plant succession related to the development stage of dune coasts were presented, among others, by Piotrowska, Gos (1995), Łabuz (2002, 2005a), Piotrowska (2003) and Łabuz, Grunewald (2007). Extensive issues related to the morpho-dynamics of dune coasts and their abrasion rate, among others, as a result of the occurrence of extreme storm surges, were presented by Łabuz (2005a), Furmańczyk, Dudzińska-Nowak (2009), Łabuz, Kowalewska-Kalkowska (2011), Wiśniewski, Wolski (2011), Furmańczyk et al. (2012). Climatic changes, sea level changes and characteristics of thermal-precipitation conditions within the coastal area of the Pomeranian Bay were dealt with, among others, by Wróblewski (1996), Furmańczyk, Musielak (1999), Plag, Tsimplis (1999), Świątek (2011), Łabuz (2012) and Tylkowski (2013a, b).

The analysis of changes and trends of dune coasts of the Pomeranian Bay over the past fifty years demonstrated that abrasion was predominant (in relation to accumulation). The Świna Gate Sandbar of is the longest section of the coastline with its long-term positive tendencies where accumulation prevailed over washout. The Polish coastal area of the Pomeranian Bay is dominated by dune sections being currently subjected to abrasion, particularly in the area of Dziwnowska and Resko Lake Sandbars (Kostrzewski, Musielak 2008, Łabuz 2013b). In order to reduce abrasion, within many sections the coastline of the Pomeranian Bay has been under protection through the construction of hydro-engineering structures. Such protective hydro-engineering structures were made not only within abrasive cliff sections, for example in Trzęsacz or Rewal but also within dune coastal sections, especially in the Kołobrzeg and Dziwnów.

The main objective of the study is to present temporal and spatial variability of abrasion of dune coastlines between 1986 and 2008. The study presents long-term tendencies and rate of the abrasion of coastal resulting from intensive storm surges. It also deals with the hydro-meteorological origin of the intensive abrasion of dunes in reference to the types of atmospheric circulation generating abrasive storm surges. Also the threshold sea level values which determine the potential intensity of dune abrasion at the Pomeranian Bay were identified.

\section{Data and methods}

The measurements of losses of dune sediments from 1986 to 2008 were the source of the data for estimated studies on dune coastal abrasion of the Pomeranian Bay. These measurements were conducted by the Maritime Offices (in Szczecin and Słupsk) at selected sections of the dune coastline of $1 \mathrm{~km}$ length that were most severely affected by the losses of sediments as a result of extreme storm surges. The results of dune abrasion expressed in cubic capacity of losses of sand volume $\left[\mathrm{m}^{3}\right]$ refer to the length of the Baltic Sea coastline - the Pomeranian Bay covers 


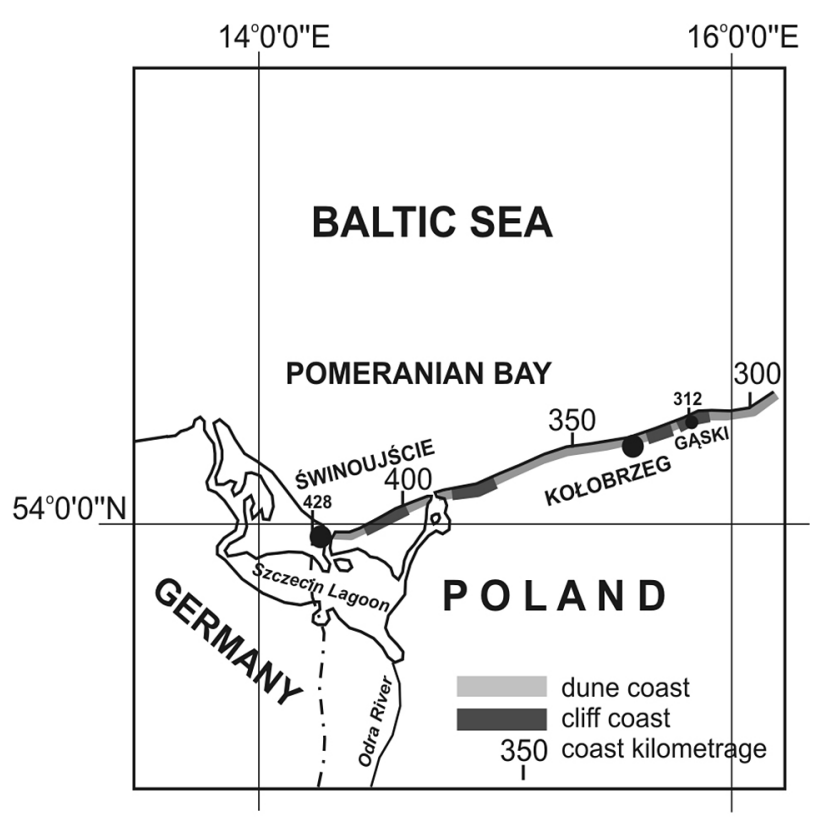

Fig. 3. Study area - dune coastal section of the Pomeranian Bay

a section from $\mathrm{km} 312$ up to $\mathrm{km} 428$ (Fig. 3). The dunes abrasion estimating was performed therefrom by a straightforward geometric field measurements by loss of sand from dune ridge on $1 \mathrm{~km}$ length sections. All the quantitative field measurements of dune abrasion were performed directly upon abrasive storms by Maritime Offices (Szczecin and Słupsk) employees. The abrasion data was received from the Maritime Office in Słupsk.

The key hydro-meteorological conditions determining the variability of the abrasion of dunes were also presented in the study. The study presents the temporal and spatial variability of average and maximal sea levels [ $\mathrm{cm}$, the Kronsztadt reference system - water gauge zero ordinate $508 \mathrm{~cm}$ ] from the mareographic stations in Kołobrzeg and Świnoujście. The daily data on the sea level from the period from 1986 to 2008 was obtained from the Institute of Meteorology and Water Management in Warsaw. The paper also deals with the types of atmospheric circulation determining the occurrence of heavy storms in the Pomeranian Bay and - as a consequence - abrasion of the dune coastlines. The daily data on the types of atmospheric circulations from 1986 to 2008 for the Polish coastal area of the Baltic Sea was determined on the grounds of the Grosswetterlagen classification conducted by the Deutscher Wetterdienst (Werner, Gerstengarbe 2010).

\section{Results}

\section{Sea level and storms}

The dune coastline - due to its low elevation above the sea level and poor resistance of the sandy sediments to abrasion is particularly vulnerable to damage as a result of increasing of the sea level and especially at high storm waves. Statistically significant increasing trends of the sea level within the Polish coastal area of the Baltic Sea has recently been observed. The analysis of average sea levels of the Pomeranian Bay between 1951 and 2009 in Kołobrzeg $(501 \mathrm{~cm})$ showed a rate of sea-level rise by 1 $\mathrm{mm} \mathrm{y}^{-1}$ (Fig. 4). The long-term dynamics of average sea level in Kołobrzeg is almost identical to sea level changes in Świnoujście. For the longtime period 1811-2006 have been found the increase of sea level in Świnoujście almost $0.5 \mathrm{~mm} \mathrm{y}^{-1}$ (Wiśniewski, Wolski 2009). The dynamics of sea level increase within the Polish coastal area of the Pomeranian Bay is similar to the global average rise of the sea level which is estimated at $1 \mathrm{~mm} \mathrm{y}^{-1}$ (Harff et al. 2007, Hünicke et al. 2008, Milne et al. 2009, Richter et al. 2012). The temporal analysis of the maximal sea level for 1986-2008 period did not indicate any statistically significant trends of its variability (Fig. 5).

The abrasion of dunes and sandy sediments outflow occur during high sea levels that significantly exceed the average sea level, which occurred for the period equal to $502 \mathrm{~cm}$ in Świnoujście and $504 \mathrm{~cm}$ in Kołobrzeg. Between 1986 and 2008 the highest sea level of $661 \mathrm{~cm}$ was recorded on 4 November 1995 in Świnoujście. In Kołobrzeg the highest sea level of $644 \mathrm{~cm}$ occurred on 1 November 2006. The absolute maximum values of the sea level were by about $1.5 \mathrm{~m}$ higher than the average sea level. Such high sea levels and their accompanying storm waves were a significant factor of dunes abrasion.

The extreme threshold values of the maximum sea levels specified in the study indicate a $10 \%$ probability of occurrence at the Gumbel distribution, according to the method of Wiśniewski, Wolski (2009) and Zwoliński (2008), Jania, Zwoliński (2011). The extreme sea level threshold in the 1986-2008 period amounted $622 \mathrm{~cm}$ in Świnoujście and $629 \mathrm{~cm}$ in Kołobrzeg. Between 1986 and 2008 the extreme sea level was recorded in Świnoujście in 2 cases (3 days: 21.02.1993, 3-4.11.1995) and in Kołobrzeg in 4 cases (4 days: 29.11.1988, 17.01.1992, 4.11.1995 and 1.11.2006). Frequency of the occurrence of extreme sea levels is higher in the western part of the Pomeranian Bay. The threshold values of abrasive sea levels specified in the study refer to the research conducted by Łabuz (2013b) who found dune abrasion at sea levels $1 \mathrm{~m}$ above the average. The specified extreme sea levels, abrasive dunes on seacoast, are about $20 \mathrm{~cm}$ higher than the alarm level which within the Polish coastline of the Baltic Sea was $\geq 600 \mathrm{~cm}$ (Wiśniewski, Wolski 2009, Tylkowski, Kolander 2014).

\section{Atmospheric circulations}

The occurrence of abrasive storm surges is determined by such variables as extensively-ranged meteorological conditions related, among others, to individual types of atmospheric circulation. The analysis of the circulation-based origin of 35 abrasive storm surges between 1986 and 2008 showed that the largest share in the generation of storms within the coastline of the Pomeranian Bay is made by cyclonal circulation. The cyclonal circulation is caused 


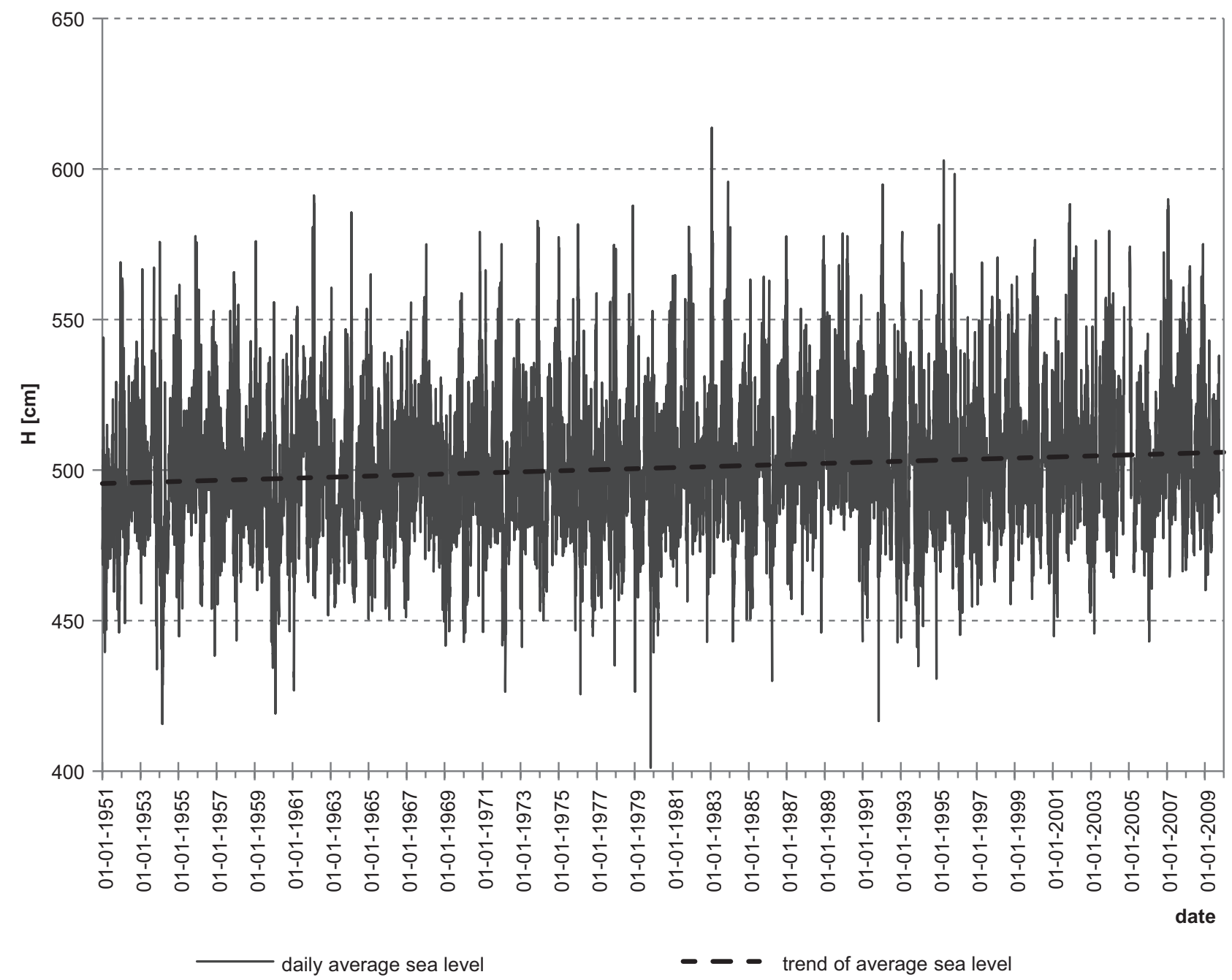

Fig. 4. Daily average sea level at the Pomeranian Bay coast in Kołobrzeg (data from Institute of Meteorology and Water Management in Warsaw)

by shift of low-pressure of baric systems and weather fronts, wind waving rises and storm surges. There was no statistically significant relationship between the type of atmospheric circulation and the intensity of the storm and dunes abrasion. It was found, however, the greater rate of dunes abrasion in the result of the presence storm surges that were generated by specific types of atmospheric circulation. The cyclonal circulation is believed to have generated occurrence of nearly $75 \%$ of storms with the largest share being due to the following types: Northwest cyclonic NWZ (29\%), West cyclonic WZ (23\%) and North cyclonic NZ (23\%). The above types of atmospheric circulations cause an inflow of air masses from the W-N sector which most often - within the Polish coast of the Baltic Sea - lead to wind waving and storm surges (Zeidler et al. 1995, Wróblewski 1996). Abrasive storm surges within the Polish coastline of the Pomeranian Bay were also formed during the occurrence of anticyclonic circulation (about 25\%), especially of the following types: Northwest anti-cyclonic NWA (14\%) and British Islands high HB $(6 \%)$. The share of abrasive sea levels generated by the following circulations: North, Iceland high, anti-cyclonic and Central European trough was negligible
(3\%). However, within the Pomeranian Bay coastline, the abrasive efficiency of storm surges caused by anti-cyclonic circulation (average losses of dunes at $40,000 \mathrm{~m}^{3}$ ) is almost 20-times lower than that during cyclonic circulation (average dune coast losses at 2,250 $\mathrm{m}^{3}$ ).

\section{Abrasion of dunes}

The coastal abrasion of the Pomeranian Bay occurred mainly in the central part of the coastline, especially from $\mathrm{km}$ 347 up to $\mathrm{km} 366$ and from km 392 up to km 400 (Fig. 6). The coastline west of Dziwnów (392-400 km) and the Resko Sandbar $(348 \mathrm{~km})$ were especially prone to losses of dune sediments $\left(>50,000 \mathrm{~m}^{3}\right.$ within the selected coastal sections with their length of $1 \mathrm{~km})$. At some points extensive abrasion of dunes $\left(>10,000 \mathrm{~m}^{3} \mathrm{~km}^{-1}\right)$ reached west of Mrzeżyno (350-358 km) and the Liwia Łuża Sandbar (364-366 km).

Abrasion of coastal dunes within the Polish coastal area mainly involved front white and - to a lesser extent - grey dunes. As a result of the abrasion of dune coasts, the natural line-based arrangement of dune ridges was disrupted. At dune-formed coasts not damaged by the 

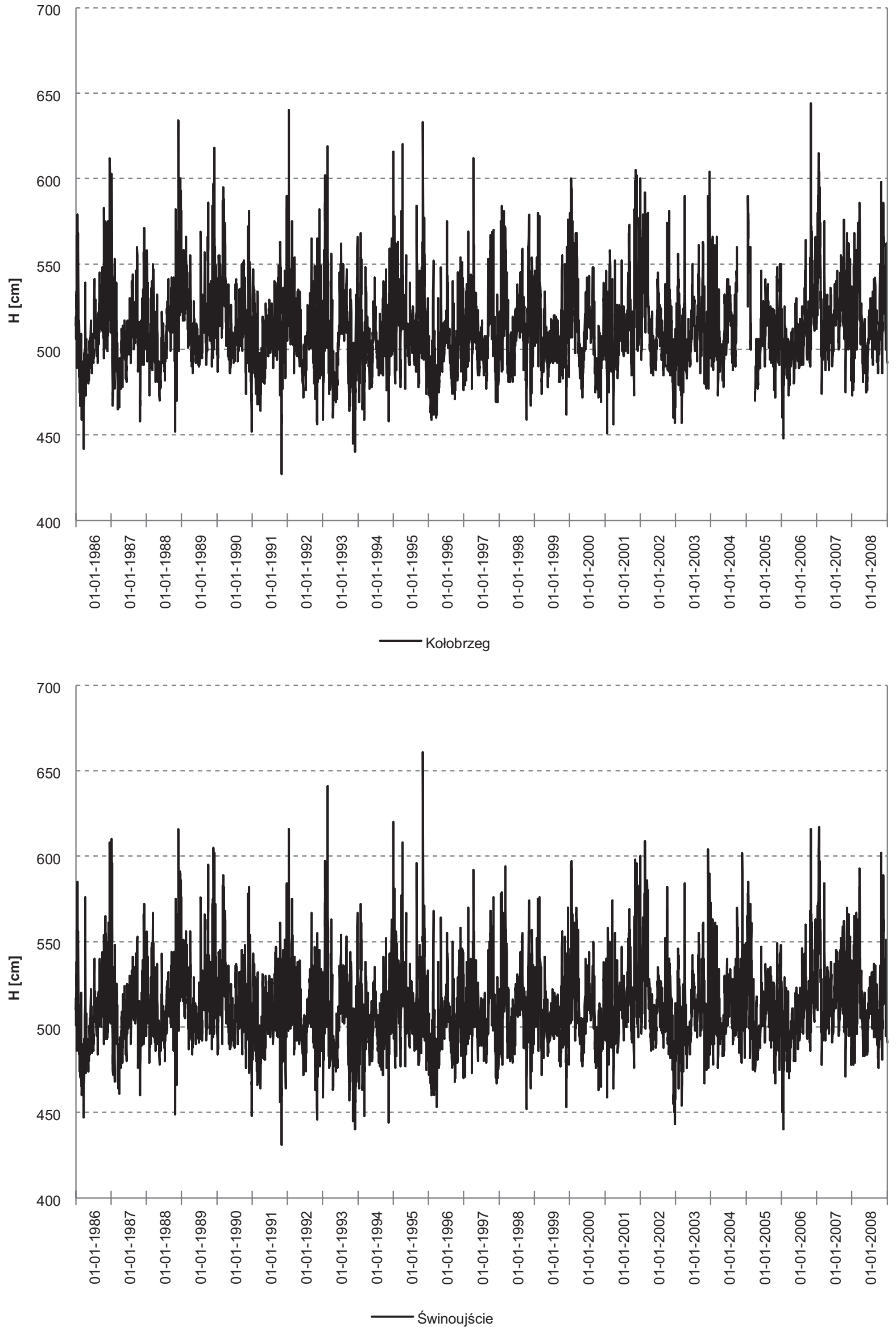

Fig. 5. Maximum daily sea level at the Pomeranian Bay coast in Kołobrzeg and Świnoujście (data from Institute of Meteorology and Water Management in Warsaw) 


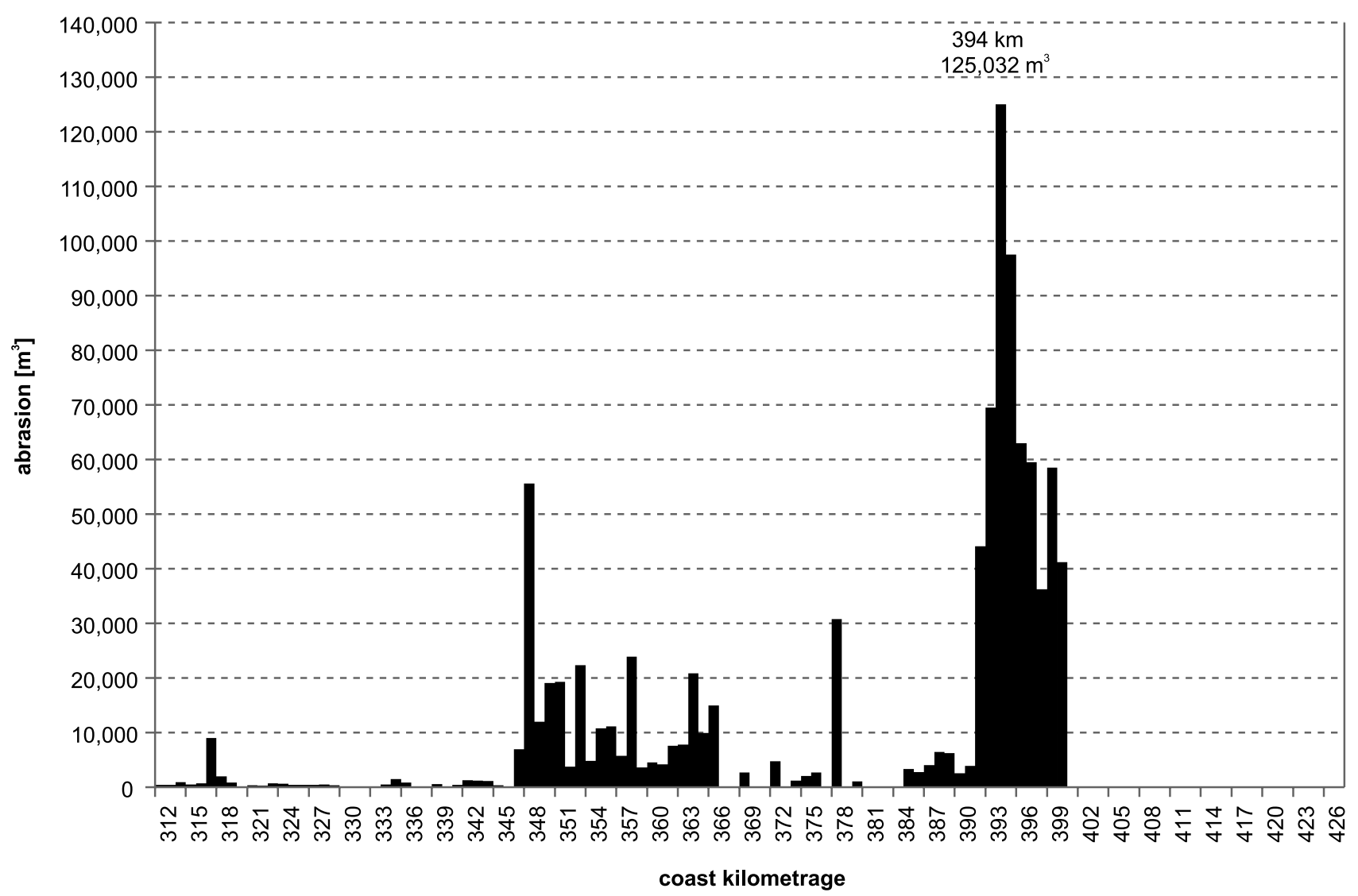

Fig. 6. Spatial variability of dunes abrasion at the Pomeranian Bay between 1986 and 2008 (data from Maritime Office in Słupsk)

abrasion varied width sandy dune ridges can be found parallel to the coastline and characterized by line-arranged vegetation (Labuz 2005a). Up to 1 meter high ephemeral embryonic dunes are located closest to the water line. There are plants characterized by high resistance to being backfilled with sand, for example Ammophila arenaria and Elymus aenarius (Carter 1990), occur at embryonic dunes. Within the coastline in front of front dunes, a significant role is also played by pioneering salt-tolerant plants: Honckenya peploides, Cakile maritima and Salsola kali. These plants - due to their adaptation to extremely difficult conditions - play a role of pioneers preparing

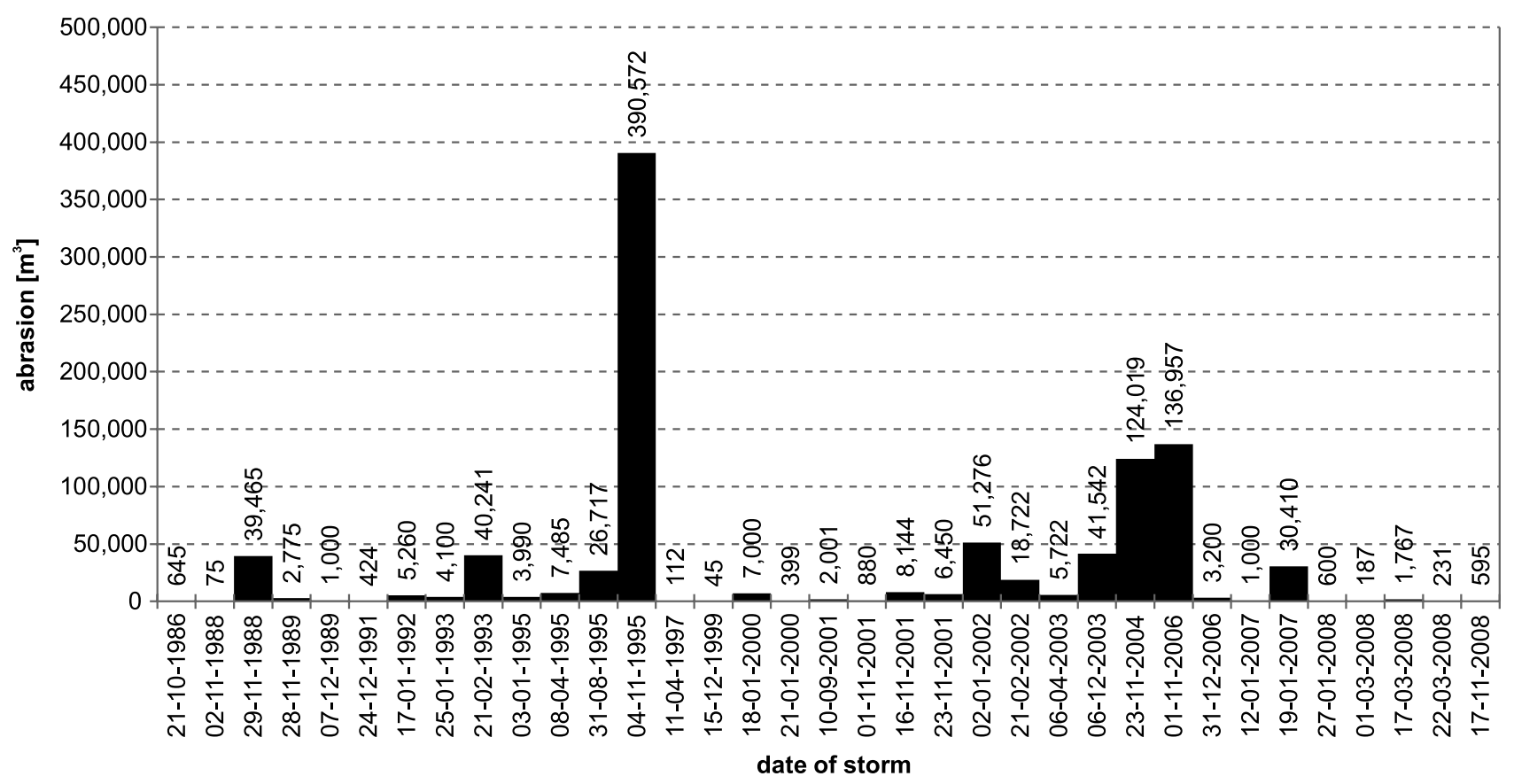

Fig. 7. Temporal variability of dunes abrasion at the Pomeranian Bay between 1986 and 2008 (data from Maritime Office in Słupsk) 
the base for succession of dune-forming plants. Further succession stages occur at more and more stable white front dunes being located further deep from the coastline at which there are mosses, lichens and sandy grassland plants from the Helichryso-Jasionetum group, for example, Hieracium umbellatum, Helichrysum arenarium, Eryngium maritimum (Piotrowska 2003). Seaside pine forest is the final link in the succession of plants at the dune coast which captures dunes completely. Pine forests (mostly consisting of trees with dominant Pinus silvestris and forest undergrowth plants) grow at grey and grown dunes (Łabuz 2003). Destruction and - very often - no occurrence of frontal dunes and losses of forest-fixed grey dunes can be an indicator of intensive abrasion of dune coasts at the Pomeranian Bay.

For the 1986-2008 period is difficult to determine a clear tendency of dunes abrasion at the Pomeranian Bay coastline. The largest losses of sediments took place in the course of extreme storm surges with their episodic and random occurrence. The extremely extensive abrasion of the coastline (nearly $400,000 \mathrm{~m}^{3}$, mainly in the Dziwnowska Sandbar zone on the $9 \mathrm{~km}$ length) was caused by a storm surge of 3-4 November 1995 (Fig. 7). The dune coast was also intensively damaged (nearly $130,000 \mathrm{~m}^{3}$ ) as a result of the storms which took place on 23 November
2004 and 1 November 2006. The specified storm surges occurred at the formation of cyclonal atmospheric circulation in the following directions: N (4 November 1995 and 1 November 2006) and NW (23 November 2004).

\section{Discussions}

Most often extensive storm surges do not cause regularly intensive abrasion of dunes along the entire Polish coastal area of the Pomeranian Bay. For example, the storm surges of 3-4 November 1995 caused a considerable level of abrasion, above all in the central part of the coastline, in the proximity of Dziwnów. Then the abrasion of dunes within $9 \mathrm{~km}$ reached the extreme level of $390,592 \mathrm{~m}^{3}$ (coastline from $392 \mathrm{~km}$ to $400 \mathrm{~km}$ ), with the largest coastal losses at $78,750 \mathrm{~m}^{3}$ recorded at $\mathrm{km} 394$ of the coastline. The storm surge of November 1995 also resulted in flooding of port quaysides in Świnoujście and local disruptions of dunes in Kołobrzeg. For the remaining part of the Pomeranian Bay coastline, its coastal abrasion was relatively less intensive, for example at the cliff coast between Grodno and Międzyzdroje the cliff crest retreated at a rate of $2.12 \mathrm{~m}$ on average (Kostrzewski et al. 2013). The extremely abrasive storm of 4-5 November 1995 emer-

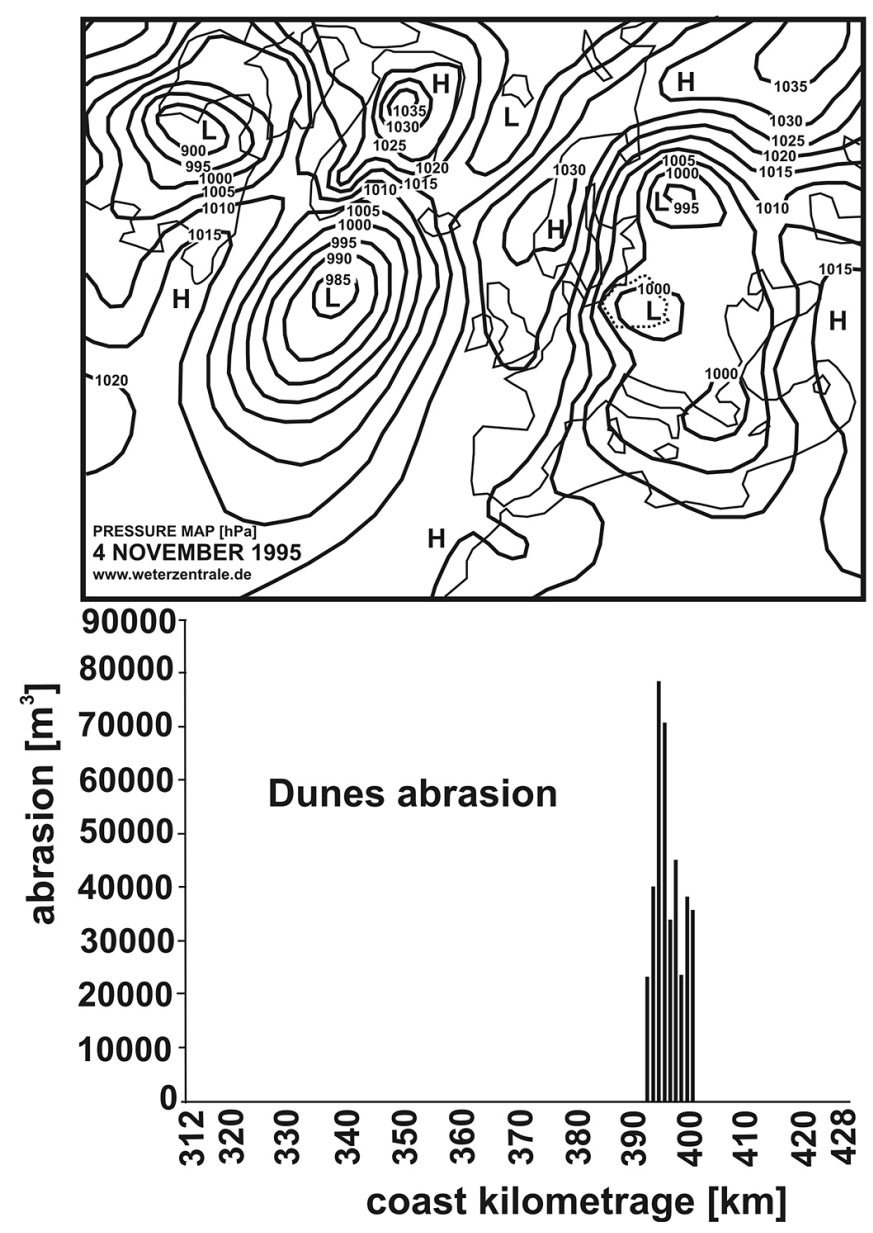

North, cyclonic atmospheric circulation

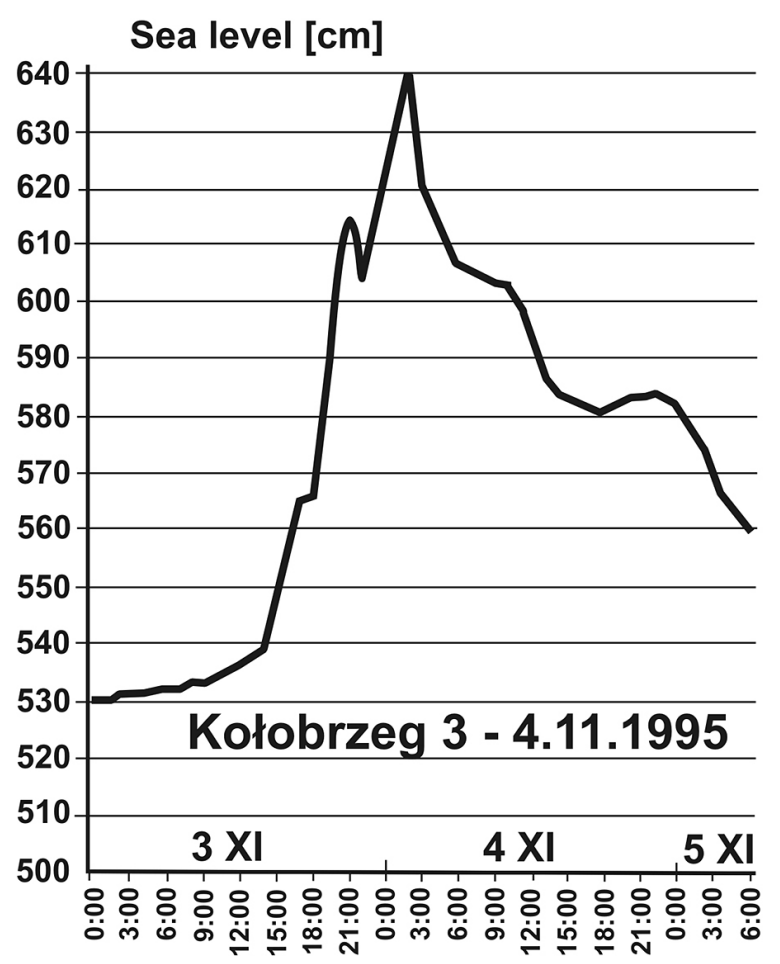

Fig. 8. Hydro-meteorological conditions of dunes abrasion at the Pomeranian Bay - the extreme event of 3-4 November 1995 (based on data from Wetterzentrale (www.wetterzentrale.de) and Maritime Office in Słupsk) 


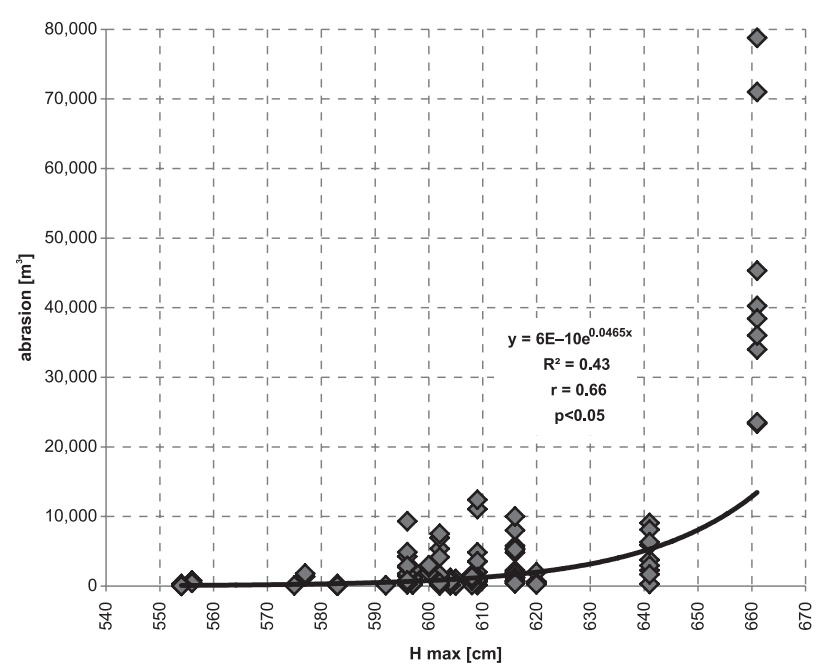

Fig. 9. Dependencies of dune abrasion $\left[\mathrm{m}^{3}\right]$ on the maximum sea level $\left[\mathrm{H}_{\max }\right]$ west of Dziwnów (at km 392-397) (data from Maritime Office in Słupsk)

ged during the formation of a deep low-pressure centre at the north-western cyclonal atmospheric circulation (Fig. 8). On the night of 4-5 November 1995 the speed of northern wind reached $35 \mathrm{~m} \mathrm{~s}^{-1}$ in Świnoujście and caused an increase in the sea level up to $669 \mathrm{~cm}$ there (and up to 640 $\mathrm{cm}$ in Kołobrzeg). During this surge the sea level was 2 $\mathrm{m}$ above the average. The maximum water level increases were $28 \mathrm{~cm} \mathrm{~h}^{-1}$ (Sztobryn, Stigge 2005).

The threshold values of the maximum sea level were determined for the dune coast of the Pomeranian Bay within the area of Dziwnów which - during the analysed period of time - was subjected to the most extensive abrasion. The abrasive sea level at which damage of dunes begins is believed to be $554 \mathrm{~cm}$ for the coastal area near Dziwnów. The threshold value of the sea level equal to 602 $\mathrm{cm}$ can cause potential abrasion $>1,000 \mathrm{~m}^{3}$ per $1 \mathrm{~km}$ of the coast and exceeding the sea level $>653 \mathrm{~cm}$ can cause extremely high abrasion over $10,000 \mathrm{~m}^{3}$ per $1 \mathrm{~km}$ of the coast (Fig. 9). But it should be emphasized that not every storm with sea level higher than the threshold designated will cause dunes abrasion.

The frequency analysis of extremely severe storm surges in reference to the threshold values of dunes at the Dziwnowska Sandbar (Furmańczyk, Dudzińska-Nowak 2009; Furmańczyk et al. 2012) presented the occurrence (between 1986 and 2008) of 16 severely abrasive storms generating losses of dunes $>5,000 \mathrm{~m}^{3}$ and 7 extremely abrasive storms with losses of dune sediments $>31,000 \mathrm{~m}^{3}$.

Taking into account the height of dunes [m] and the cubic capacity of their abrasion $\left[\mathrm{m}^{3}\right]$, the positional changes [m] of their bases can be estimated over the reported period [1986-2008]. On the basis of the morphometry changes of dunes ridges and the cubic volume of dunes sand (which was taken away as a result of abrasion) you can specify the rate of withdrawal of the base of dunes at abrasive sections. At the Pomeranian Bay coast the annual rate of dunes withdrawal can be estimated less than $1 \mathrm{~m}$. Similar tendencies in of changes at the abrasion-affected sections of the dune coastline were reported in the stud- ies developed by Zawadzka-Kahlau (1999), Łęcka, Furmańczyk (2005) and Łabuz $(2009,2012)$. On the dune coast of Pomeranian Bay in the 1986-2008 period the potential greatest withdrawal of dune ridges occurred in the near Dziwnowska Sandbar (on average $15.2 \mathrm{~m}$ at the coast section from 392 up to $397 \mathrm{~km}$, maximally $35.7 \mathrm{~m}$ at $394 \mathrm{~km}$ ). In fact such so significant withdrawal of dune coast prevented natural factors (related to the accumulation of sandy sediments within the dune coastal area as the result of the occurrence of littoral and aeolian processes) and anthropogenic activities connected with the protection of the sea coastline. The protection of the dune coast was based on the performance of infilling the beaches and construction of protective hydro-engineering structures (e.g. rock- and concrete-based bands and blocks) and bio-technical constructions (e.g. plantings, reconstruction of dune ridges).

\section{Conclusions}

The intensity of dunes abrasion at the Pomeranian Bay coast does not demonstrate any proportional dependency in relation to high sea-levels. It was not always the case that storm surges caused intensive abrasion of the coastline. A significant role in the process of coastline abrasion was played by the durations and frequencies of inter-storm periods when it comes to the accumulation of sediments within the under-shore, especially within the tidal area. The tidal area having a considerable amount of clustered sediments constitutes the main area of concentration of wave energy and at the same time reduces the abrasion of coastal dunes.

The dunes abrasion in the Pomeranian Bay during the 1986-2008 period presents no clear temporal and spatial trends. The particularly intensive destruction dune coast occurred mainly at the Dziwnowska Sandbar (at km 392397 , average annual abrasion $3,003 \mathrm{~m}^{3} \mathrm{~km}^{-1}$ ) and coast section from Resko Lake Sandbar to Liwia Łuża Sandbar (at $\mathrm{km}$ 347-366, average annual abrasion $610 \mathrm{~m}^{3} \mathrm{~km}^{-1}$ ), with a $27 \mathrm{~km}$ total length, which is almost $40 \%$ of the dune coastal at the Pomeranian Bay. The intensity of dune coasts abrasion does not have a development trend and is not subject to cyclical and seasonal fluctuations. The extreme dunes abrasion on sea coast is the result of incidental occurrence of extreme events, mainly storm surges in 1995, 2004 and 2006.

The extreme dunes abrasion at the Pomeranian Bay in the analyzed period was the result of the extreme storm surges occurrence, when the daily maximum sea level was higher than $622 \mathrm{~cm}$. The extreme storm surges were initialized during the movement of low atmospheric pressures on the Baltic Sea, during the occurrence of cyclonic atmospheric circulation from $\mathrm{N}-\mathrm{W}$ sector. The geomorphological transformations of Pomeranian Bay coast are the result of extreme events, mainly extreme storm surges. The estimated dunes abrasion during the extreme storm surges occurrence (only 5 causes in 6 days during 
22 years) has reached $64 \%$ of the total dunes abrasion at the Pomeranian Bay in the analyzed multi-year.

\section{Acknowledgements}

The Maritime Offices in Gdynia, Słupsk, Szczecin supported this study by supplying data on the abrasion of dunes. Special thanks to the Director of Maritime Office in Słupsk Mr. Tomasz Bobin for the data on losses in the coastal dunes. Special thanks to the Director of Hydrological and Meteorological Service Mr. Rafał Bakowski for the sea level data.

The study was co-financed as part of project No. N N304 NCN 274340 on the Current condition and functioning of the natural environment in selected areas of the West Pomerania in view of the climate change and human impact.

\section{References}

Bird E.F.C., 1990. Foreword. In: K.F. Nordstrom, N.P. Psuty, B. Carter (eds), Coastal dunes. Form and processes. John Wiley \& Sons, Chichester: $2-5$.

Bohdziewicz L., 1963. Przegląd budowy geologicznej i typów polskich wybrzeży. Materiały do monografii polskiego brzegu morskiego. Geologia i Zagadnienia Pokrewne 5, IBW PAN, Gdańsk-Poznań: $10-41$.

Borówka R.K., 1990. Coastal dunes in Poland. In: T.W. Bakker, P.D. Jungerius, J.A. Klijn (eds.), Dunes of the European coasts. Catena Supplement 18: 25-30.

Borówka R.K., 1999. Multi-year trends of change in intensity of potential aeolian transport on the West Pomeranian coast of the Baltic in the context of the morphology and present-day development of coastal dunes. In: R.K. Borówka (ed.), Late Glacial, Holocene and present-day evolution of the coastal geosystems of the Southern Baltic. Quaternary Studies in Poland Special Issue: 67-75.

Carter R.W.G., 1988. The geomorphology of coastal dunes in Ireland. In: T.W. Bakker, P.D. Jungerius, J.A. Klijn (eds), Dunes of the European coasts, Catena Suplement 18: 31-40.

Carter R.W.G., Wilson P., 1990. The geomorphological, ecological and pedological development of coastal foredunes at Magilligan Point, Northern Ireland. In: K.F. Nordstrom, N.P. Psuty, B. Carter (eds), Coastal dunes. Form and processes. John Wiley \& Sons, Chichester: $129-157$.

Furmańczyk K., Dudzińska-Nowak J., 2009. Extreme storm impact on the coastline changes - South Baltic example. Journal of Coastal Research SI 56: 1637-1640.

Furmańczyk K.K., Dudzińska-Nowak J., Furmańczyk K.A., Paplińska-Swerpel B., Brzezowska N., 2012. Critical storm thresholds for the generation of significant dune erosion at Dziwnow Spit, Poland. Geomorphology 143-144: 62-68. http://dx.doi.org/10.1016/j.geomorph.2011.09.007

Furmańczyk K.; Musielak S., 1999. Circulation systems of the coastal zone and their role in South Baltic morphodynamic of the coast. Quaternary Studies in Poland. Special Issue: 91-94.

Harff J., Lemke W., Lampe R., Lüth F., Lübke H., Meyer M., Tauber F., Schmölcke U., 2007. The Baltic Sea coast - A model of interrelations among geosphere, climate, and anthroposphere. In: J. Harff, W.W. Hay, D.M. Tetzlaff (eds), Coastline Changes: Interrelation of Climate and Geological Processes. Geological Society of America Special Paper 426: 1-10.

Hünicke B., Luterbacher J., Pauling A., Zorita E., 2008. Regional differences in winter sea-level variations in the Baltic Sea for the past 200 years. Tellus 60(A2): 384-393.
Jania J.A., Zwoliński Z., 2011. Ekstremalne zdarzenia meteorologiczne, hydrologiczne i geomorfologiczne w Polsce. Landform Analysis 15: 51-64.

Kolander R., Morche D., Bimböse M., 2013. Quantification of moraine cliff coast erosion on Wolin Island (Baltic Sea, northwest Poland). Baltica 26(1): 37-44.

Kondracki J., 2000: Geografia regionalna Polski. Wydawnictwo Naukowe PWN, Warszawa, 1-440.

Kostrzewski A., 1985. Variation in the particle-size distribution and degree of sand grain abrasion in morainic till of the Wolin Island, NW Poland. Quaternary Studies in Poland 6: 83-97.

Kostrzewski A., Musielak S., 2008. Współczesna ewolucja rzeźby Południowego Bałtyku. In: L. Starkel, A. Kostrzewski, A. Kotarba, K. Krzemień (eds). Współczesne przemiany rzeźby Polski. Institute of Geography and Spatial Management of the Jagiellonian Univeristy, Kraków: 327-348.

Kostrzewski A., Zwoliński Z., 1988. Morphodynamics of the cliffed coast, Wolin Island. Geographia Polonica 55: 69-81.

Kostrzewski A., Zwoliński Z., 1995. Present-day morphodynamics of the cliff coasts of Wolin Island. Journal of Coastal Research SI 22: 293-303.

Kostrzewski A., Zwoliński Z., Samołyk M., Tylkowski J., Winowski M., 2013. Morfosystem wybrzeży klifowych wyspy Wolin - monitoring ostrzegawczy, program ochrony. In: A. Kostrzewski, Z. Zwoliński, M. Winowski (eds.) Geoekosystem wybrzeży morskich, 2. Uwarunkowania i funkcjonowanie wybrzeży morskich, Poznań-Biała Góra: 59-62.

Krygowski B., Krygowska L., Kostrzewski A., 1966. Piaski plażowe z Międzyzdrojów, Zeszyty Naukowe UAM, Geografia 6: 5-7.

Łabuz T.A., 2002. Pokrycie plaż roślinnością wydmotwórczą wskaźnikiem dynamiki wybrzeża Zatoki Pomorskiej. Czasopismo Geograficzne 73(3): 245-256.

Łabuz T.A., 2003. Initial foredune field as a factor of accumulative character of coastal dunes of the Swina Gate Barrier (West Polish coast). Oceanological and Hydrobiological Studies 32(1): 39-58.

Łabuz T.A., 2004. Coastal dune development under natural and human influence on Swina Gate Barrier (Polish coast of Pomeranian Bay). In: G. Schernewski, N. Löser (eds.), Managing the Baltic Sea. Coastline Reports 2(2004) EUCC: 129-138.

Łabuz T.A., 2005a. Present-day dune environment dynamics on coast of the Swina Gate Barrier (West Polish Coast). Estuarine Coastal and Shelf Science 62(3): 507-520. http://dx.doi.org/10.1016/j. ecss.2004.09.014.

Łabuz T.A., 2005b. Brzegi wydmowe polskiego wybrzeża Bałtyku. Czasopismo Geograficzne 76(1-2): 19-47.

Łabuz T.A., 2009. The West Pomerania coastal dunes - alert state of their development. Zeitschrift der Deutschen Gesellschaft für Geowissenschaften 160(2): 113-122. http://dx.doi.org/10.1127/18601804/2009/0160-0113.

Łabuz T.A., 2012. Coastal Response to Climatic Changes: Discussion with Emphasis on Southern Baltic Sea. Landform Analysis 21: 43-55.

Łabuz T.A., 2013a. Polish coastal dunes - affecting factors and morphology. Landform Analysis 22: 33-59. doi: http://dx.doi.org/10.12657/ landfana.022.004.

Łabuz T.A., 2013b. Sposoby ochrony brzegów morskich i ich wpływ na środowisko przyrodnicze polskiego wybrzeża Bałtyku. Raport WWF, $1-180$.

Łabuz T.A., Grunewald R., 2007. Studies on vegetation cover of the youngest dunes of the Świna Gate Barrier (West Polish coast). Journal of Coastal Research 23 (1): 160-172. http://dx.doi.org/10.2112/030119.1

Łabuz T.A., Kowalewska-Kalkowska H., 2011. Coastal erosion on the Świna Gate Sandbar (southern Baltic Sea) caused by a heavy storm surge in November 2004. Climate Research, Special Issue 48: $93-$ 101. http://dx.doi.org/10.3354/cr00927.

Łabuz T.A., Olechnowicz P., 2004. Rekonstrukcja rozwoju rzeźby akumulacyjnego brzegu wydmowego na podstawie struktur sedymentacyjnych - studium przypadku z Mierzei Bramy Świny. In: M. Błaszkiewicz, P. Gierszewski (eds), Rekonstrukcja i prognoza zmian środowiska przyrodniczego w badaniach geograficznych. Prace Geograficzne 200 IG i PZ PAN Warszawa: 237-248. 
Łęcka A., Furmańczyk K., 2005. Wizualizacja trójwymiarowa w badaniach strefy brzegowej na przykładzie obliczeń objętości materiału erodowanego i akumulowanego na brzegu morskim. Roczniki Geomatyki 3 (4): 127-136.

Milne G.A., Gehrels W.R., Hughes C.W., Tamisiea M., 2009. Identifying the causes of sea level change. Nature Geoscience 2: 471-478.

Musielak S., 1995. Shoreline dynamics between Niechorze and Świnoujście. In: K. Rotnicki (ed.), Polish coast: past, present, future. Journal of Coastal Research SI 22: 288-291.

Nordstrom K.F., 2000. Beaches and dunes of developing coasts. Cambridge University: 1-280. http://dx.doi.org/10.1017/CBO9780511 549519.

Piotrowska H., 2003. Zróżnicowanie i dynamika nadmorskich lasów i zarośli w Polsce. Bogucki Wydawnictwo Naukowe Poznań-Gdańsk, 1-104.

Piotrowska H., Gos K., 1995. Coastal dune vegetation in Poland. Diversity and development. In: H.W.J. van Dijk (ed.), Management and preservation of coastal habitats. Proceedings of multidisciplinary workshop in Jastrzębia Góra. EUCC Leiden Netherlands: 71-82.

Plag H.P., Tsimplis M.N., 1999. Temporal variability of the seasonal sea-level cycle in the North Sea and Baltic Sea in relation to climate variability. Global and Planetary Change 20: 173-203.

Racinowski R., 1995. Cechy litodynamiczne podbrzeża Mierzei Dziwnowskiej w świetle badań uziarnienia i składu minerałów ciężkich rumowiska. Marine Sciences 3: 7-48.

Richter A., Groh A., Dietrich R., 2012. Geodetic observation of sea-level change and crustal deformation in the Baltic Sea region. Physics and Chemistry of the Earth 53-54: 43-53.

Sydor P., Łabuz T.A., Mańkowska A., 2011. Struktury sedymentacyjne i uziarnienie osadów wydm i plaży wybrzeża Bałtyku w rejonie Pogorzelicy. Czasopismo Geograficzne 82(3): 213-233.

Subotowicz W., 1982. Litodynamika brzegów klifowych wybrzeża Polski. Gdańskie Towarzystwo Naukowe Ossolineum Wrocław: 1-150.

Sztobryn M., Stigge H.J., Wielbińska D., Weidig B., Stanisławczyk I., Kańska A., Krzysztofik K., Kowalska B., Letkiewicz B., Mykita, M., 2005. Storm Surges in the Southern Baltic Sea (western and Central Parts). Berichte des Bundesamt für Seeschiffart und Hydrgraphie 39: $1-74$.

Świątek M., 2011. Precipitation changes on the Polish coast of the Baltic Sea (1954-2003) due to changes in intensity of westerlies over Europe. Climate Research 48: 23-29.
Tomczak A., 1995. Geological structure and Holocene evolution of the Polish coastal zone. In: K. Rotnicki (ed.), Polish Coast: Past, Present and Future. Journal of Coastal Research SI22: 15-31.

Tylkowski J., 2011. Wpływ zmian poziomu morza na funkcjonowanie strefy brzegowej Bałtyku w Kołobrzegu. In: A. Kostrzewski, J. Szpikowski, R. Woźniak (eds), Wpływ zmian klimatu i narastającej antropopresji na rozwój Uzdrowiska Kołobrzeg. Regionalne Stowarzyszenie Turystyczno-Uzdrowiskowe w Kołobrzegu, Kołobrzeg: 53-64.

Tylkowski J., Samołyk M., 2011: Zmienność przestrzenna powierzchniowych osadów plażowych brzegu morskiego wyspy Wolin. Badania Fizjograficzne nad Polską Zachodnią R.IIA62/2011: 151-163.

Tylkowski J., 2013a. Temporal and spatial variability of air temperature and precipitation at the Polish coastal zone of southern Baltic Sea. Baltica 26(1): 83-94.

Tylkowski J., 2013b: Charakterystyka rocznej temperatury powietrza, termicznych pór roku i sezonu wegetacyjnego w Dziwnowie. Monitoring Środowiska Przyrodniczego 14: 125-131.

Tylkowski J., Kolander R., 2014. Potential hydrometeorological threshold values of the coastal hazard an example from the Polish Southern Baltic coast. Russian Meteorology and Hydrology 39(9): 614-619.

Werner P.C., Gerstengarbe F.W., 2010. Katalog der Grosswetterlagen Europas (1881-2009). PIK Report No. 119, Potsdam Institute for Climate Impact Research: 1-146.

Wiśniewski B., Wolski T., 2009. Katalogi wezbrań i obniżeń sztormowych poziomów morza oraz ekstremalne poziomy wód na polskim wybrzeżu. Wydawnictwo Akademii Morskiej Szczecin: 1-156.

Wiśniewski B., Wolski T., 2011. Physical aspects of extreme storm surges and falls on the Polish coast. Oceanologia 53(1-TI): 373-390.

Wróblewski A., 1996. Seasonal forcing of baltic water volumes by the meteorological fields over the basin from 1896 to 1970 . Oceanologia 38(4): 529-541.

Zawadzka-Kahlau E, 1999. Tendencje rozwojowe polskich brzegów Bałtyku Południowego. GTN Gdańsk: 1-147.

Zawadzka-Kahlau E., 2012. Morfodynamika brzegów wydmowych południowego Bałtyku. Wydawnictwo UG Gdańsk: 1-353.

Zeidler R.B., Wróblewski A., Mietus M., Dziadziuszko Z., Cyberski J., 1995. Wind, wave and storm surge regime at the Polish Baltic Coast. In: K. Rotnicki (ed.) Polish Coast- Past, Present and Future. Journal of Coastal Research SI22: 33-55.

Zwoliński Z., 2008. Wybrane zjawiska ekstremalne pojezierzy polskich. Landform Analysis 8: 98-106. 